\title{
Phrases of Maybrat
}

Lulu Jola Uktolseja

lulujola39@gmail.com

Sherly Gaspersz

Sherlygaspersz91@gmail.com

\section{Universitas Victory Sorong}

\begin{abstract}
The objectives of the study are to describe (1) Attributive endocentric phrases, (2) Appositive endocentric phrases, (3) Coordinative endocentric phrases, and, (4) Exocentric phrases. The research methodology used in this research is qualitative descriptive method. Techniques for collecting data in this research are the observation and interviewing the informants. In analyzing the data, the researcher used the tagmemic methods. The informants of this research are the people of Maybrat region who lived in $\mathrm{Jl}$. Tanjung Dofior Belakang Unamin. The informants have fulfilled the requirements given by the researcher. The approach used in this study was bilingual approach, instead of monolingual approach, that is, by asking the informants to translate the words (phrases) from Bahasa Indonesia to Maybrat language. The result of this research is the phrase of Maybrat language divided into two kinds as general, they are endocentric and exocentric phrase. It is also classified into noun phrase, pronoun phrase, verb phrase, adjective phrase and pre(post) position phrase. Each phrase has its own pattern. Some of them are similar into English and Indonesian, but some are really different.
\end{abstract}

Keywords: Language; Phrases; Maybrat

\section{INTRODUCTION}

Language is in first place a mean of communications, a sign system, and no such system would work without sharp distinctions (Ebeling in Fautngil, 2011). Every country has its own language, and Indonesia is one of the countries that have many local languages. Indonesia has more than 746 local or regional languages. West Papua as the province which so rich with its heritage, definitely has many local languages. In West Papua there are many local languages spread around West Papua. Papuan languages (PL) spoken in New Guinea and neighboring islands, perhaps the third largest language family in the world.

The linguistic research shows us the way for cultivating and preserving the documentations of regional language. It is important to act quickly in order to capture the languages before it extincts. Thus, the young generations will have 
knowledge about their regional languages. And they also can keep that language shine as property for the future life.

One of the local languages in Papuan Languages is Mai brat or Ayamaru language. The Ayamaru language, or Mai Brat, is spoken by the Maybrat people in the many villages around the Ayamaru Lakes on the Bird's Head Peninsula of West Papua. It is only distantly related to other languages, sharing $10 \%$ of its vocabulary with its nearest neighbors (apart from the very similar Karon Dori), though it may be part of the West Papuan family. Variant spellings of the language include Majbrat, Mey Brat, and Brat. Other names include Atinjo and Maite. Ayamaru is fairly isolating, with subject-verb-object and noun-adjective word order.

Concerning the characteristics, Maybrat has some interesting phenomena in its phrase. O'Dwyer (2000) states that phrases are word groups having internal cohesion and forming syntactic units within sentences. A head word is the single word around which other words group for meaning. Based on the information that the writer got from Summer Institute of Linguistics (SIL), the study of Maybrat language especially about phrase is none. There are several studying about this language but only about its vocabulary, pronoun and folktale story. Hence, the writer was challenged to write its phrases. Hopefully, this study will be one of references for the young generation of Papua. This research will explain the phrase for each part of endocentric and exocentric then also phrases in sentences.

\section{LITERATURE REVIEW}

\section{Previous Related Study}

Various research and studies on the subject of this research have been carried out previously by another researcher. But based on the information that the researcher got from Summer Institute of Linguistics (SIL), there are some researches done by the other researcher about personal pronoun, folktale, vocabulary, conversation and another cases. But there is not previous study about phrase. The researcher takes the information from Glottolog, there is several research may be able to be a review of relevant research. Dol (2007) conducted research entitled "A grammar of Maybrat: A language of the bird's head peninsula, Papua province, Indonesia".

Waren (2006) from Universitas Negeri Papua also conducted the research entitled "Pronouns In Maybrat Language of Ayamaru dialect: Morpho-Syntax persperctive". In her research, she explained interesting phenomenon of Maybrat; its possessive pronouns are divided into alienable form and inalienable form. Alienable possessive are ro- and a-, whereas inalienable possessive are t- to first person singular; $\mathrm{n}$ - to second person singular, first person plural, and second person plural; $y$ - to third person singular (man); and $\mathrm{m}$ - to third person singular (woman) and third person plural. These possessives are categorized into prefix. Furthermore, the data were analysed by using the morpho-syntax analysis and the descriptive method. 
Many research have conducted by those certain researchers, but there is no one research which is analysing phrase in Maybrat completely. Whereas phrases in Maybrat can be analyzed from many point of view. The researcher of this study "Phrases of Maybrat" wants to give the complete explanation about phrase to the reader especially people of Maybrat. The researcher hopes that this research will enrich the information about Papuan language, especially Maybrat language.

\section{Phrases}

In ordinary, nontechnical language, phrase can simply mean a group of words. In syntax, however, it has a more precise meaning. There are many opinions about phrase. Therefore, in this analysis of Maybrat language have chosen two of those opinions as the basic in this analysis. Verhaar (2001) explained that phrase is the group of word which is the functional part of long utterance. According to Chaer (2003:222) phrase is the grammatical unit which is the combination of words and it has non-predicative characteristic, or usually says as the word combination and it fills one function of syntax in sentence. Phrase is a group of words which forms a grammatical unit and it has non-predicative characteristic. Phrases can be divided into two types, they are 1) based on function; and 2) based on word class.

\section{Phrases based on the Function}

Distribution in linguistic means all positions placed by the elements of language. A phrase formed by several elements included words or some words which will form the phrase. Based on the relationship between the phrase and its constituent, phrases are classified or divided into two types, they are endocentric phrase and exocentric phrase.

Endocentric phrase is the phrase when one of its elements or component has same syntax action as the whole elements (Suherlan \& Odien, 2004:206). Endocentric phrases are classified into three kinds, they are: Attributive Endocentric Phrase, Appositive Endocentric Phrase and Coordinative Endocentric Phrase.

Attributive Endocentric Phrase is the phrase includes of unequal element, hence its element is impossible to connect with conjunction and or or (Ramlan, 2001: 143). For instance, the phrase handsome boys similar to one of the constituents that is boys. The nuclear of the phrase is called head and the one that modifies is called modifier or attribut. Other attributive endocentric phrase are: beautiful woman, run fast, very cute, etc.

Appositive endocentric phrase is the phrase which does not have connection with conjunction and or or and semantically it element is only one (Ramlan, 2005:144). Suherlan \& Odien (2004:208) stated that appositive endocentric phrase is endocentric phrase that each shaper unsure has same information and conformation. In this kind of phrase the constituents refer to the same thing. Both constituents can 
have their places exchanged. For example, Mr. Rahman, our teacher, will teach us tomorrow.

Coordinative endocentric phrase is when each constituents of a phrase has the same level or consist of equal element. Its equality proved by the possibility of those element connected by the conjunction and or or. For instance, you and I in You and I love apple pie is coordinative, because you and I are the same level. But sometime the conjunction is not used. In this kind of phrase both constituents are head, there is no attributive.

Exocentric phrase is the phrase which does not have the same distribution or class as one of the constituents. In this kind of phrase there is no head and no modifier. Preposition is the mark of exocentric phrase. The phrase at school, does not have the same class as either at or school, because at school is adverb of place, while at is function word which does not mean anything without other word, and school is a noun.

\section{Phrases based on the Word Class}

Phrases can be divided into noun phrase, verb phrase, adjective phrase, pronominal phrase, adverb phrase, pre(post) positional phrase and numeral phrase. This article limits the description only to noun phrase, verb phrase, adjective phrase, pronominal phrase, prepositional phrase.

A noun phrase is a phrase that has the head belonging to noun. For the example, big house and small town, these phrases are noun phrase. The head of big house is house, which is house is classified as noun. As the second example small town, the head is town which is classified as noun. On the other hand, a verb phrase is a phrase with a verb head or a phrase that function as a verb. For instance, come late, just came, etc. Then, an adjective phrase is a phrase that has an adjective as the head, such as very good, too high, not good, rather stupid, etc. A pronominal phrase is a phrase in which pronominal is the head of the phrase. For instance, you and $\underline{\mathrm{I}} \underline{\mathrm{my}}$ house, his girlfriend, etc. A prepositional phrase is a phrase that consists of a preposition and a noun or a relater and axis.

\section{METHOD}

\section{Design and Samples}

This research was qualitative research with descriptive method. Suryana (2010:19) stated that the descriptive method is the method used to find the elements, characteristic, property of a phenomenon. This method begins by collecting, analyzing and interpreting the data. In language study we have to explain the linguistic school used to describe the phrase of Maybrat. There are several schools used to describe the language whether transformational grammar, traditional grammar, or structural linguistics or tagmemeics. And the way used in this study to 
describe Maybrat phrase is two-cell tagmemics (tagmemics of two cells) as described by Elson and Pickett (1964) instead of four cells (Pike, 1977). Two cells means the way we describe the phrase with states slot (function) and filler (word classes).

\section{Instrument and Procedure}

Observation and interview are the instrument of this research. The tool of collecting data in this study is a set of phrase in Indonesia arranged to provoke phrase in Maybrat language. The tool of collecting data including various noun phrases, verb phrases, adjective phrases, pre (post) positional phrases and pronoun phrases. Presence of the researcher in the qualitative research is so important. The approach used in this study was bilingual approach, instead of monolingual approach, that is, by asking the informants to translate the words (phrase) from Bahasa Indonesia to Maybrat language.

\section{Data Analysis}

In analyzing the data, the researcher used the methods used by Elson and Pickett, and Thomas, as written in their books An Introduction to Morphology and Syntax and Introduction to Grammatical Analysis. Pike proposed tagmemic analysis in four cells; slot, class, role and cohesion. But the technique used in this study is tagmemic technique which is simplifying by Elson and Pickett, this analysis with use two cells; slot and class. Each structure of phrase will explain based on its elements (slot function and word class) whether obligatory or optional. All structure has each pattern.

\section{RESULTS AND DISCUSSION}

Maybrat is one of the Papuan languages of West Papuan Phylum found in the Bird's Head of New Guinea Island, in which it is spoken in the central area which is also called as Maybrat (Dol, 1999: 1). Maybrat language has two kinds of phrase, they are endocentric and exocentric phrase.

\section{Endocentric Phrase}

\section{Noun Phrase}

Maybrat language has two kinds of noun phrases, they are as attributive endocentric noun phrase and coordinative endocentric noun phrase.

\section{a. Attributive Endocentric Noun Phrase}

1) Noun Phrase with A Possessive Noun Attribute

Patterns of noun phrase with a possessive noun attribute divided into two kinds. The first pattern is: $\mathbf{+} \mathbf{M}: \mathbf{n}+\mathbf{H}: \mathbf{n}$ (compulsory modifier filled with noun followed by compulsory head filled with noun). For example, Kukait $m a=$ Cassowary's feet. Kukait (Cassowary = Modifier), $m a(f e e t=h e a d)$. It can be identified that Maybrat language especially noun phrase with noun as modifier that states possession in Maybrat language has the same 
structure with English language, where the modifier comes first and followed by head. On that example, feet on that example is the property of the core phrase cassowary. Feet is something inherent in cassowary. It can be explained that every phrase that uses a noun as modifier and it is attached to or owned by the noun as head of the phrase, the formula used is $+\mathbf{M}: \mathbf{n}$ $+\mathbf{H}: \mathbf{n}$.

The second pattern is $\mathbf{+} \mathbf{H}: \mathbf{n}+\mathbf{M}: \mathbf{n}$ (the compulsory head filled with noun followed by compulsory modifier filled with noun). For example, Samu kok $=$ Chicken's stable. Samu (Stable $=$ head), kok (chicken $=$ modifier $)$. In the second pattern $+\mathbf{H}: \mathbf{n}+\mathbf{M}: \mathbf{n}$, described by the example above that attribute noun declared property of the core is something that is not attached directly to the core of the phrase.

\section{2) Noun Phrase with the Possessive Pronoun as Modifier}

Noun phrase with the possessive pronoun as modifier is the phrase which compulsory head filled with noun with followed by modifier filled with a compulsory pronoun (I, you, we, they, he, she) which explain the possession. The pattern is: $+\mathbf{H}: \mathbf{n}+\mathbf{M}:$ pro. For example, Amah ajo = my house. Amah (house = head), ajo (my = modifier).

\section{3) Noun Phrase with A Noun attribute as Whole Part}

A noun phrase with a noun attribute stating part is a phrase consisting of a head of nouns and noun as modifier that shows part. The structural formula is: $+\mathbf{M}: \mathbf{n}+\mathbf{H}: \mathbf{n}$. For example, son mata $=$ Coconut leaves. Son (coconut $=$ modifier), mata (leaves $=$ head).

\section{4) Noun Phrase with Adjective as Modifier}

This phrase consisting of elements such as nouns with the following attributes are adjectives. This phrase structural formula is: $+\mathbf{H}: \mathbf{n}+\mathbf{M}$ : adj. For example, mtis maboh $=$ big root. Mtis $($ root $=$ head $)$, maboh $($ big $=$ modifier).

\section{5) Noun Phrase with Numeral as Modifier}

This phrase consists of a head element in the form of nouns with the attributes that form numeral. The formula of this phrase: $\mathbf{+} \mathbf{H}: \mathbf{n}+\mathbf{M}: \mathbf{n u m}$. For example, ara ewok = two pieces of wood. Ara $($ wood $=$ head $)$, ewok $($ two $=$ modifier $)$.

6) Noun Phrase with Demonstrative Pronoun as Modifier

This phrase consists of a head element in the form of the noun with the attribute is a demonstrative pronoun. This phrase structural formula is:: + $\mathbf{H}$ : $\mathbf{n}+\mathbf{M}$ : dem.pro (demonstrative pronoun). For example, Fra reto = That Stone. Fra (stone $=$ head $)$, reto $($ that $=$ modifier $)$.

\section{7) Noun Phrase more than Two Words}


This phrase is a group of words consisting of three or more words that has one sense. Noun phrase consists of head elements and attributes. One phrase structural formula is: + H : n + M1 : adj + M2 : dem.pro (demonstrative pronoun). For example, Mtis maboh reto $=$ That big root. Mtis (root $=$ head $)$, maboh $($ big $=\bmod 1)$, reto $($ that $=\bmod 2)$.

\section{b. Coordinative Endocentric Noun Phrase}

The coordinative endocentric phrase divided into 2 (two).

1) Noun Phrase which states Sum Coordinative

What is meant by the phrase indicating endocentric nominal sum is nominal phrase which consists of two core elements of its equal and connected by 'msya' ... .. and. This phrase structural formula is + $\mathbf{H}: \mathbf{n}+$ Connector : conjuction (msya) $+\mathbf{H}: \mathbf{n}$. For example, Mti mesya bas $=$ Day and night. Mti $($ day $=$ head $)$, mesya $($ and $=$ con $)$, bas $($ night $=$ head $)$.

\section{2) Noun Phrase that indicates Selection}

Endocentric noun phrase that indicates selection is a noun phrase consisting of two core elements of its equal and connected with the word ' $f e$ ' which states a choice. This phrase structural formula:+ H : $\mathbf{n}+\mathbf{C o n}: \mathbf{c o n j}(\mathbf{f e})+$ $\mathbf{H}: \mathbf{n}$. For example, Snyife to sken $=$ Moon or star. Snyi $($ moon $=$ head $)$, fe to $($ or $=$ con $)$, sken $($ star $=$ head $)$.

\section{Pronoun phrase}

Pronoun phrase in Maybrat language divided into attributive endocentric phrase and coordinative endocentric phrase.

a. Attributive Endocentric Pronoun Phrase

1) Pronoun phrase with collective numeral as modifier

The pronoun phrase with collective numeral as modifier is the phrase that essentially consists of pronominal with the modifier is numeral or words that expressed combination. This phrase formula is: $+\mathbf{H}:$ pro $+\mathbf{M}$ : col.num (collective numeral). For example, Ana mbewok $=$ both of them. Ana $($ they $=$ head $)$, mbewok $($ two $=$ modifier $)$.

\section{2) Pronoun Phrase with Demonstrative Pronoun as Modifier}

This phrase essentially consists of a demonstrative pronoun as modifier. Which in Maybrat, the demonstrative pronoun is not always the same, where the demonstrative pronoun will be adjusted to the following word. There is no indication that the pronoun must be the same in every use, as in English 'this' or 'that'. The structural formula is: $+\mathbf{H}:$ pro $+\mathbf{M}:$ dem.pro (demonstrative pronoun). For example, Jo/ji mefi $=$ this me. Jo/ji $(I=$ head), mefi $($ this $=$ modifier ).

\section{3) Pronoun Phrase with Attributive Appositive Noun Phrase}

This phrase consists essentially of pronoun with noun as modifier or noun phrase that has a function to add information on the previous expression. 
This formula of this phrase is: $\mathbf{+} \mathbf{H}:$ pro $+\mathbf{M}: \mathbf{N P}$. For example, Ana ra $m a b i=$ 'They, old men'. Ana (they $=$ head $), r a$ (people), mabi (men = modifier).

\section{4) Pronoun Phrase with Verb as Modifier}

This phrase consists essentially of pronouns with the verb as modifier. If necessary translated word 'that' between pronouns and verbs. In the language of Maybrat marked with the word ' $r o$ ' as explanatory what did by the pronoun. The formula of this phrase is: $\mathbf{+} \mathbf{H}: \mathbf{p r o}+\mathbf{M}: \mathbf{v}$. For example, Amu ro nhoh $=$ we, running. Amu (we = head), ro (who), nhoh (run = modifier).

\section{b. Coordinative Endocentric Pronoun Phrase}

Coordinative endocentric pronoun phrase is a phrase consisting of two core elements whose has equal position and connected with the word ' $m s y a$ ' meaning and, as well as the word ' $f e$ ' which states an option. This phrase structural formula is: $+\mathbf{H}:$ pro + Connector $:$ conj $+\mathbf{H}$ : pro. For example, Nyo msya ait $=$ you and him. Nyo $($ you $=$ head $)$, msya $($ and $=$ conj $)$, ait $($ him $=$ head $)$.

\section{Verb Phrase}

Verb phrase can be divided into attributive endocentric verb phrase and coordinative endocentric verb phrase.

a. Attributive Endocentric Verb Phrase

1) Verb Phrase with Adverb of Manner as Modifier

This phrase structure consists of attributes that are filled by adverbial of manner that must be followed by the core which is filled by verbal mandatory. This structure can be formulated as follows: $+\mathbf{H}: \mathbf{v}+\mathbf{M}$ : adv.manner. For example, Nait foh $=$ eat quickly. Nait $($ eat $=$ head $)$, foh $($ fast $=$ modifier $)$.

\section{2) Verb Phrase with Modal/Aspect as Modifier}

The structure of this phrase, preceded by the attribute that is filled by the modal / aspect followed by a verb as the core. The pattern is defined as follows: $+\mathbf{H}: \mathbf{v}+\mathbf{M}: \mathbf{m o d} / \mathbf{a s p}$ (modal/aspect). For example, Nit toh $=$ may eat. Nit $($ eat $=$ head $)$, toh $($ may $=$ modifier $)$.

\section{3) Verb Phrase with Adverb of Time as Modifier}

This phrase consists of attributes that form adverbial of time followed by a core which is filled by the verb. Actually, in the Maybrat language verb phrase that indicates an action that moves, cannot stand alone without the subject. So it can be seen in the example below for instance 'Yehai' does not have a pure verb, because letter $y$ in Yehai indicate the deceased was a man. The formula is: $+\mathbf{H}: \mathbf{v}+\mathbf{a d v . t}$ (adverb of time). For example, Nama menrabu $=$ come tomorrow. Nama $($ come $=$ head $)$, menrabu $($ tomorrow $=$ modifier). 
4) Verb Phrase with adverb of manner which showing intensity as modifier

The structure of this phrase consist of adverb of manner which showing intensity followed by verb as head. This one is similar to verb with adv of manner, but not manner (action: fast, slow) like 'stay very long', walk very far, work very hard, etc. The word "sai aa" is showing the intensity. The pattern of this phrase: $+\mathbf{H}: \mathbf{v}+\mathbf{a d v . m}$ (adverb of manner). For example, Here kait sai a $=$ sit so long. Here $($ sit $=$ head $)$, kait $(l o n g=$ modifier $)$, sai aa $($ so $=$ modifier $)$.

\section{5) Verb Phrase with Negator as Modifier}

This phrase consists of obligatory attributes are filled by negator followed by a compulsory head which is filled by the verb. This phrase formula is: $\mathbf{H}$ : $\mathbf{n}+\mathbf{M}$ : negator. For example, $n m o f e=$ not go. Nmo $(\mathrm{go}=\mathrm{head})$, fe (not $=$ modifier).

6) Verb Phrase with Negative Adverb of Manner as Modifier

This phrase consists of compulsory attributes are filled by adverbial followed by core required by the verb. When this verb has an object, this object can be placed before the adverbial or before negator, while negator always after the verbs and objects. For example, nekah bo farin toni fe = not work very hard. Nekah bo (work = head), farin toni (hard very $=$ modifier $)$, fe $($ not $=$ negator $)$.

\section{7) Verb Phrase with Tool as Modifier}

This phrase consists of attributes filled by compulsory head as verb and followed modifier is filled by objects that are used as captions. In the structure there is the word 'Mekah' ... with, which is used as descriptors for the use of the tool to do a job. Placement of the word 'Mekah' is placed at the center between the verb and tools. This phrase pattern is as follows: $\mathbf{+} \mathbf{H}$ : v + M : pp (Prepositional phrase). For example, Ketan mekah sogi $=$ cut with machete. Ketan (cut = head), mekah (with = modifier), sogi (machete).

\section{b. Coordinative Endocentric Verb Phrase}

This phrase must consist of a head which is filled by the verb followed by a second core which is also filled by verb. In this phrase there are conjunctions that serve to explain the relationship between the first verb and the later. The conjunctions are "mesya and Tena" meaning and. The pattern of this phrase is: $\mathbf{+} \mathbf{H}: \mathbf{v}+\mathbf{M}: \mathbf{c o n j}+\mathbf{H}: \mathbf{v}$. For example, Nroh mesya nut $=$ up and down. Nroh (up = head), mesya $($ and $=$ conj), nut $($ down $=$ head $)$.

\section{Adjective Phrase}

a. Attributive Endocentric Adjective Phrase

1) Adjective Phrase with Positive Degree as Modifier

Adjective phrase with comparable levels of positive attributes explained that the state / trait nouns / pronouns are the same as other nouns / pronouns. 
Attribute of this phrase is the word menan anya and hroh wen, meaning the same. This phrase pattern is as follows:: $+\mathbf{H}: \mathbf{a d j}+\mathbf{M}: \mathbf{a d v}$. For example, my menan any $=$ as all as. $M y($ tall $=$ head $)$, menan any $($ same $=$ modifier $)$.

\section{2) Adjective Phrase with Comparative Degree as Modifier}

This comparison used to declare a state or trait noun or pronoun that one more than any other noun or pronoun. This attribute is ro phrase, which means more. The pattern of this phrase is as follows: $\mathbf{H}: \mathbf{a d j}+\mathbf{M}: \mathbf{a d v}$. For example, myи ro $=$ taller. Myu $($ tall $=$ head $)$, ro $($ more $=$ modifier $)$.

\section{3) Adjective Phrase with Superlative Degree as Modifier}

The level of this ratio is used to describe the situation or the nature of the noun or pronoun that the above condition or the nature of some or all of the other noun or pronoun. Attribute this phrase is in syok, that means the most. The pattern of this phrase is $\mathbf{+} \mathbf{H}: \mathbf{a d j}+\mathbf{M}$ : adv (syok). For example, myu syok $=$ the tallest. $M y u($ tall $=$ head $)$, syok $($ most $=$ modifier $)$.

\section{4) Adjective Phrase with Negator as Modifier}

This phrase begins the head is an adjective and followed by negator ' $f e$ or fares' which means no. In use fe and fares have the same meaning and the same function. The formula of this phrase is as follows: + H: adj + M: negator. For example, mof $f e=$ not good. Mof (good $=$ head $)$, fe $($ not $=$ modifier).

\section{5) Adjective Phrase with Excessive Adverb as Modifier}

This phrase is preceded by the adjective as the head, followed by modifier such as adverbial, in Maybrat language the use 'tony' which means too. This phrase pattern is $+\mathbf{H}: \mathbf{a d j}+\mathbf{M}: \mathbf{a d v}$. For example, myo toni $=$ too long. Myo $($ long $=$ head $)$, toni $($ too $=$ modifier $)$.

6) Adjective Phrase with Augmentative Adverb as Modifier

This phrase begins with the compulsory head is adjective, followed by compulsory modifier adverbial form marked with the word 'baro' meaning getting or more and more. This phrase formula is: $+\mathbf{H}: \mathbf{a d j}+\mathbf{M}: \mathbf{a d v}$. For example, myo baro $=$ getting longer. Myo $($ long $=$ head $)$, baro $($ getting $=$ modifier).

7) Adjective Phrase with Elative Adverb as Modifier

This phrase preceded by adjective as the head, followed by the word 'toni' meaning too or very. In use, the same as the attribute excessive adjectival phrase.. The pattern of this phrase is: $+\mathbf{H}: \mathbf{a d j}+\mathbf{M}: \mathbf{a d v}$ 'toni'. For example, myo toni $=$ very long. Myo $($ long $=$ head $)$, toni $($ very $=$ modifier $)$.

b. Coordinative Endocentric Adjective Phrase

1) Sum Coordinative Endocentric Adjective Phrase 
This phrase is formed with a core of one with the other core is connected with the conjunction ' $m s y a$ ' meaning and. This phrase pattern is as follows: + H1: adj + M: conj + H2: adj. This phrase preceded by first core (compulsory), which is filled adjectives, followed by conjunctions msya (required) and then followed by a second core (compulsory) in the form of adjectives. For example, mkek msya mboh = red and white. Mkek (red = head), msya (and = modifier), mboh ( white $=$ head).

\section{2) Selection Coordinative Endocentric Adjective Phrase}

This phrase is formed with a core of one with the other core is connected with the conjunction ' $f e$ ' meaning or. This phrase pattern is as follows: + H1: adj + M: conj + H2: adj. For example, sioh fe ati $=$ lie or true. Sioh $($ lie $=$ head $)$, fe $($ or $=$ modifier $)$, ati $($ true $=$ head $)$.

\section{3) Coordinative Endocentric Adjective Phrase without Conjunction}

In this phrase that the relationship between the core with the other core is not connected by any conjunctions. This phrase formula is as follows: $\mathbf{+} \mathbf{H}$ : $\mathbf{a d j}+\mathbf{H}$ : adj. Adjective phrase is preceded by the first core (compulsory) filled by adjectives, followed by a second core (compulsory) filled adjectives anyway. For example, safe mof = black sweet. Safe (black = head), mof (sweet $=$ head).

\section{Exocentric Phrase}

\section{Prepositional Phrase}

a. Prepositional Phrase That Marked Relations Provisions

Prepositional phrase that marked the relationship between the provisions established by the prepositional marking provisions are meant to do that, then followed by a noun or pronoun core form or description. For example, $m k a h n y u=$ for you. Mkah (for = relator $),$ nyu $($ you $=$ axis $)$.

\section{b. Prepositional Phrase and Postpositional Phrase}

\section{1) Prepositional Phrase}

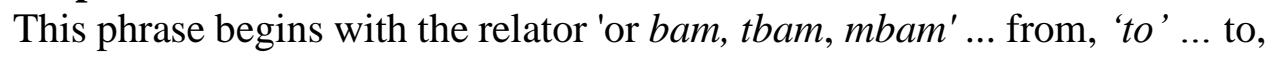
' $m a$ ' ... at, akah ... above, then followed by axis which can be filled by a word/phrase or pronoun. Prepositional phrase showed in the phrase which showed location. For example, to amah $=$ to the house. To $($ to $=$ relater $)$, amah (home $=$ axis).

\section{2) Postpositional}

This phrase begins with the axis which can be filled by a word / phrase or pronoun then followed by relator ' $o h$ '... after or before, 'refo' . ... in, 'tis' ... behind. Prepositional phrase showed in the phrase which showed time and manner.

$\underline{\text { Time }}$

$\begin{array}{ll}\text { Rabu } & \text { refo } \\ \text { Morning } & \text { in } \\ \text { Axis } & \text { Relater }\end{array}$




\title{
Noun Preposition
}

'In the morning'

\author{
Manner \\ Meran teto \\ Like that \\ Axis Relater \\ Noun Prepositional \\ 'Like that'
}

\section{CONCLUSION}

The Maybrat language has a variety of unique phrase patterns, such as when differentiated by function or word class. Based on the data result and discussion of this study, the writer can take the conclusions. The phrase in Maybrat language divided into two kinds as general, they are endocentric and exocentric phrase. Where also classified into noun phrase, pronoun phrase, verb phrase, adjective phrase and pre(post)position phrase. Each phrase has its own pattern. The general pattern of noun phrase is head followed by modifier. But in several kinds of noun phrase, it has more than two patterns. Such as noun phrase with a possessive noun attribute has two patterns. First, where the compulsory modifier filled with noun followed by compulsory head filled with noun. Second, where the head (noun) came first and then followed by the modifier (noun). The same case also showed in the part of noun phrase with the possessive pronoun as modifier, it also has two patterns. First, where the compulsory modifier filled with noun followed by compulsory head filled with noun. Second, where the head (noun) came first and then followed by the modifier (noun). The noun where came in the beginning such as amah ajo or the noun where came in the last such as ju amah. And also there is a noun phrase which only has one pattern, where the modifier came first then followed by head. It is noun phrase with a noun attribute as the whole part. Maybrat language generally has both prepositional and postpositional phrase. This is a special identification of Maybrat language, which is unusual like the other Papuan languages generally that only has postpositional phrase. Prepositional used to show location. The place of relator in this phrase is at the beginning of the phrase (prepositional) like those in the other languages such as English and Indonesia. Whereas postpositional phrase showed in time and manner. The general pattern of pronoun phrase in Maybrat language is head followed by modifier. The position of modifier in pronoun phrase is always after the verb (head). Besides several kinds of pronoun phrase which only structured head and connected by connector to the second head. Such as endocentric noun phrase which states sum coordinative, nominal endocentric phrase that indicates a selection and coordinative endocentric pronoun phrase (CEPP). The general pattern of verb phrase in Maybrat language is head followed by modifier. Besides several kind of verb phrase which only structured by head and followed head such as coordinative endocentric 
adjective phrase without conjunction (CEAPW-C). The position of modifier in adjective phrase is always after the adjective (head). The coordinative phrase is connected by msya .... And, $f e$.... Or. The position of $f e$ "not" is at the end of the verb phrase.

\section{REFFERENCES}

Chaer, A. (2003). Linguistic Umum. Jakarta:Rineka Cipta.

Elson, B., \& Velma, P. (1964). An Introduction to Morphology and Sintax. Huntington Beach: Summer Institute Of Linguistics.

Fautngil, C. (2011). Linguistik. Malang: Surya Pena Gemilang.

O'Dwyer, B. (2000) Modern English Structures: Form, Function, and Position. Canada: Broadview Press.

Purba. (2011). Linguistic. Jayapura: Cendrawasih University.

Ramlan, M. (2001). Ilmu Bahasa Indonesia Sintaksis. Yogyakarta: CV. Karyono. (2005). Ilmu Bahasa Indonesia Sintaksis. Yogyakarta: CV. Karyono.

Sugiyono. (2004). Metode Penelitian Bisnis. Bandung: Alfabeta.

Suherlan., \& Odien, R. (2004). Ihwal Ilmu Bahasa dan Cakupannya. Serang: Untirta Press.

Suryana. (2010). Metodologi Penelitian: Model Praktis Penelitian Kuantitatif dan Kualitatif. Buku Ajar Perkuliahan UPI.

Verhaar, J. W. M. (2001). Asas-Asas Linguistic. Yogyakarta:Gadjah Mada University Press.

Waren, O. U. (2006). Pronouns in Maybrat Language of Ayamaru Dialect: MorphoSyntax Perspective. State University of Papua, Manokwari. 118pp. (MA thesis). 